\title{
Visual Detection of Curly Top Virus by the Colorimetric Loop-Mediated Isothermal Amplification
}

\author{
Mohammad Amin Almasi ${ }^{1}$, Mehdi Aghapour-ojaghkandi ${ }^{2 *}$ and Saeedeh Aghaei ${ }^{2}$ \\ ${ }^{1}$ Department of Agriculture and Plant Breeding, Faculty of Agriculture, Zanjan University, Zanjan, Iran \\ ${ }^{2}$ Young Researchers and Elite Club, North Tehran Branch, Islamic Azad University Tehran, Iran
}

\begin{abstract}
Curly Top Virus (CTV) in sugar beet, belonging to the family Geminiviridae, genius Curtovirusis a considerable problem in semiarid areas of the Iran and other semiarid parts of the world. There are several diagnostic methods to detect CTV, But these techniques take a long time for $3 \mathrm{~h}$ to tow day, requiring sophisticated tools. The aim of this study, for the first time, was to reduce the time required to detect CTV in sugar beet, using colorimetric loop-mediated isothermal amplification (LAMP) technique requiring only an ordinary water bath or thermoblock.DNA was extracted from infected naturally leaf tissues. Samples were tested for the presence of Curtovirus species by PCR and LAMP reactions to amplify replication-associated protein (rep) gene using species primers. LAMP was optimized to amplify CTV DNA under isothermal conditions by incubation at $63^{\circ} \mathrm{C}$ for $30 \mathrm{~min}$. LAMP products were detected visually using the different dyes. The LAMP amplification products had a ladder-like appearance when electrophorised on an agarose gel and also positive results using the different dyes were a color change. Results confirmed LAMP with different dyes provides a rapid and safe assay for detection of CTV in sugar beet. Since with other molecular methods, equipping laboratories with a thermocycler or expensive detector systems is unavoidable, this assay was found to be a simple, cost-effective molecular method that has the potential to replace other diagnostics in primary laboratories without the need for expensive equipment or specialized techniques. It can also be considered as a reliable alternative viral detection system in further investigations.
\end{abstract}

Keywords: Curly top virus; Colorimetric assay; LAMP reaction; Sugar beet

\section{Introduction}

Curly top is one of the most devastating DNA viruses, causing curly top diseases in a wide range of plants. It can be caused by a number of closely related species in the genus Curtovirus of the family Geminiviridae. These viruses are transmitted by the beet leafhopper (Circulifertenellus Baker) and can infect dicotyledonous hosts from 44 families and at least 300 species [1,2]. The viruses responsible for curly top diseases have been separated into three distinct species, based largely on sequence variation in select regions of the curtovirus genome, as well as some differences in host range and disease severity [3]. Curly top disease (CTD) of sugar beet and several crops such as tomato, pepper, bean, cucurbits, tobacco and potato is a known disease affecting these crops for over a century $[4,5]$. Different symptoms caused by curly top viruses include stunting, leaf curling, vein swelling and yellowing, crumpling, and hyperplasia of the phloem. Early infection causes early death in plants [6,7]. CTD is caused by several curtoviruses, including beet curly top virus (BCTV), Beet Severe Curly Top Virus (BSCTV), Beet Mild Curly Top Virus (BMCTV), Horseradish Curly Top Virus (HrCTV), Spinach Curly Top Virus (SpCTV) and Pepper Curly Top Virus (PepCTV). Furthermore, two divergent curly top viruses, Beet Curly Top Iran Virus (BCTIV) and Turnip Curly Top Virus (TCTV), have been reported from Iran in the past five years [812]. Recombination has also been suggested to have played a part in the evolution of species in this group [13]. BCTV may have arisen by recombination between a whitefly-transmitted geminivirus, which may have donated the complementary genes involved in virus replication, and a leafopper-transmitted geminivirus, which donated the coat protein gene [14].

Curtovirus species possess a monopartite genome with circular single-stranded DNA of approximately $3 \mathrm{~kb}$ with three over overlapping virion sense genes ( $V 1, V 2$, and $V 3$ ), four overlapping complementary sense genes $(C 1, C 2, C 3$, and $C 4)$, and an intergenic region containing the origin of replication [15-18]. During the period from the 1950s to the 1970s a broad range of curly top isolates were described and some were noted to have increased in severity [19]. Some alternative approaches were gradually developed including polymerase chain reaction (PCR), Rolling-circle amplification (RCA), Restriction fragment Length Polymorphism (RFLP) and Chromatin immunoprecipitation (ChIP) assays, all of which were unfortunately time-consuming and require expensive or carcinogenic materials to visualize DNA amplification [20-23].

Among various isothermal amplification systems developed over the recent years, the most frequently applied approach seems to be loop-mediated isothermal amplification (LAMP), implemented first by Notomi et al. [24]. Due to its enormous rate of amplification paired with a very high specificity, sensitivity, rapidity and low artifact susceptibility, the method together with its modifications have been strongly recommended for detection of a great number of strains of bacteria as well as viruses worldwide [25]. Briefly, each reaction is carried out by the use of a DNA polymerase with strand displacement activity and set of four different primers: F3 (forward outer primer), B3 (backward outer primer), FIP (forward inner primer), BIP (backward

*Corresponding author: Mehdi Aghapour-Ojaghkandi, Young Researchers and Elite Club, North Tehran Branch, Islamic Azad University Tehran, Iran, E-mail: mehdiagh3@gmail.com

Received August 03, 2013; Accepted September 11, 2013; Published September 17, 2013

Citation: Almasi MA, Aghapour-Ojaghkandi M, Aghaei S (2013) Visual Detection of Curly Top Virus by the Colorimetric Loop-Mediated Isothermal Amplification. J Plant Pathol Microb 4: 198 doi:10.4172/2157-7471.1000198

Copyright: ( $) 2013$ Almasi MA, et al. This is an open-access article distributed under the terms of the Creative Commons Attribution License, which permits unrestricted use, distribution, and reproduction in any medium, provided the original author and source are credited. 
inner primer), designed specifically to recognize six distinct regions on the target sequence in conjunction with two loop primers: LF (loop forward) and LB (loop backward) to accelerate the reaction [24,26]. LAMP assay, alternately, can also amplify nucleic acid under isothermal condition in the range of $60^{\circ} \mathrm{C}-65^{\circ} \mathrm{C}$, all turbidity and fluorescent based detections, as well as agarose gel electrophoresis system are applied to visualize suspicious samples [24-26]. LAMP has been shown to be as sensitive and specific as real-time PCR, and several LAMP assays have been developed for the detection of different plant viruses and viroids [27-29]. Here, for the first time, LAMP technique based on visualization system was consequently employed to detection of CTV in sugar beet.

\section{Materials and Methods}

\section{Plant samples and extraction of total DNA}

Samples were collected from the sugar beet production areas in Iran such as East-Azarbaigan where curly top has been observed. Sugar beet (Beta vulgaris L.) leaf samples symptomatic for curly top were collected between 2012 and 2013.

Leaf tissue was sampled by punching out a disk with the cap of a sterile $2 \mathrm{ml}$ microcentrifuge tube and stored at $-80^{\circ} \mathrm{C}$. Individual tubes containing the frozen tissue were dipped in liquid nitrogen and then pulverized using a Retsch MM 301 mixer mill (Retsch, Inc., Newton, PA) with $5 \mathrm{~mm}$ stainless steel beads. DNA was extracted using a DNeasy Plant Mini Isolation kit (Qiagen, Inc., Valencia, CA) following standard protocols suggested by the manufacturer, except DNase and RNase free water (W4502, Sigma-Aldrich, St. Louis, MO) was used in place of Buffer AE in the final steps. The DNA was stored at $-20^{\circ} \mathrm{C}$.

\section{PCR and LAMP primers}

PCR and LAMP assays were developed using specific primers designed based on replication-associated protein (rep) gene (GenBank accession AF379637.1). PCR (Forward and Backward) and LAMP specific primers were designed using the Oligo7 and Primer ExplorerV4 software (specific for LAMP) respectively (Table 1). In addition, Figure 1 shows the position of the PCR and LAMP primers on rep gene. At LAMP assay, six primers recognizing eight distinct regions in the target sequence were used, including Outer primers (F3 and B3), Inner primers (FIP and BIP) and Loop primers (LF and LB). Moreover, each primer was tested for similarities with other sequences available in the GenBank databases (http://blast.ncbi.nlm.nih.gov/Blast.cgi) using the BlastN algorithm.

\section{PCR reaction}

PCR were performed in volumes of $25 \mu \mathrm{l}$ with the componentsin the master mix at the following concentrations: $1 \times \mathrm{PCR}$ buffer (GeneAmp 10×PCR Gold buffer with 150 mMTris-HCl, pH 8.0, 500 mMKCl; Applied Biosystems, Foster City, CA), $2.5 \mathrm{mM} \mathrm{MgCl}_{2}$ (Applied
Biosystems), 1.4 mMdNTPs (Applied Biosystems), $0.2 \mathrm{M}$ each of $\mathrm{F}$ and B primer, 0.625 UAmpliTaq Gold (Applied Biosystems), and $2 \mu$ DNA. Amplification consisted of $5 \mathrm{~min}$ at $95^{\circ} \mathrm{C}$ followed by 34 cycles $95^{\circ} \mathrm{C}$ for $1 \mathrm{~min}, 54^{\circ} \mathrm{C}$ for $1 \mathrm{~min}$, and $72^{\circ} \mathrm{C}$ for $1 \mathrm{~min}$. After the last cycle, the reaction was held at $72^{\circ} \mathrm{C}$ for $5 \mathrm{~min}$ and then $4^{\circ} \mathrm{C}$. PCR amplification products were visualized with agarose gel electrophoresis, $1.5 \%$ in TAE buffer and visualized by staining with ethidium bromide under UV light. To determine specificity of the primers, LAMP and PCR reactions were carried out to BCTV (Beet Curly Top Virus) DNA as positive control.

\section{Colorimetric LAMP reaction}

In order to select the most appropriate condition, LAMP reaction was conducted according to procedures published previously [24-27]. The amplification reaction was performed at $63^{\circ} \mathrm{C}$ for $30 \mathrm{~min}$ in water bath by mixing $1.6 \mathrm{M}$ each of FIP and BIP primer, $0.2 \mathrm{M}$ each of $\mathrm{F} 3$ and B3 primer, $0.8 \mathrm{M}$ each of LF and LB primer, $1.4 \mathrm{mMdNTPs}, 0.8 \mathrm{M}$ betaine (Sigma-Aldrich, Saint Luis, MO, USA), 8U of BstDNA polymerase (New England Biolabs, Hertfordshire, England, UK) using the supplied buffer (Thermopol buffer containing $2 \mathrm{mM}$ of $\mathrm{MgSO}_{4}$ ) and $2 \mu \mathrm{l}$ DNA. As an additional proof, products from the reaction were also analyzed by agarose gel electrophoresis. Various colorimetric assays including magnesium sulfate $\left(\mathrm{MgSO}_{4}\right)$, Calcium chloride $\left(\mathrm{CaCl}_{2}\right)$, SYBR ${ }^{\circledR}$ Premix Ex Taq ${ }^{\mathrm{TM}}$ II, Hydroxyl naphthol blue (HNB), GeneFinder ${ }^{\mathrm{TM}}$, SYBR Green I and Ethidium bromide have been proposed and used in several investigations [30-41]. Here, thus, the validations of positive LAMP reactions were justified by means of these seven staining approaches.

\section{Magnesium sulfate}

Like other metal indicators, magnesium sulfate must be added before reaction. At the end of the amplification process, positive reactions were accompanied by a visible darker phase in the tubes in consequence of the formation of magnesium pyrophosphate which can be easily visualized with the naked eye $[24,35]$. It is noticeable that the turbidity of the positive samples is stable but just for a short time, which should be consequently judged soon after taking out of the samples either from the water bath or the thermal cycler.

\section{Calcium chloride}

Use of $\mathrm{MgSO}_{4}$ in LAMP reaction in order to create turbidity has some drawbacks such as, low stability and concentration. In this research, we used $\mathrm{CaCl}_{2}$ to address these disadvantages as described previously by Almasi et al. [38]. Thus, $2 \mathrm{mM} \mathrm{CaCl}_{2}$ was added to LAMP mixture to improve both stability and concentration of turbidity in the reaction.

\section{SYBR $^{\circledR}$ Premix ExTaq ${ }^{\mathrm{TM}}$ II}

To conquer time-dependent instability of magnesium or calcium

\begin{tabular}{|c|c|c|c|c|c|}
\hline Reaction & Primer & Type & $\begin{array}{l}\text { Length of } \\
\text { Primer }\end{array}$ & Sequence $\left(5^{\circ}-3^{\prime}\right)$ & $\begin{array}{l}\text { Length of } \\
\text { Product }\end{array}$ \\
\hline PCR & $\mathrm{F}$ & Forward & $24 \mathrm{nt}$ & TGCTCCAATAAGGTGCTTCCAGTG & \multirow{2}{*}{292 bp } \\
\hline PCR & B & Backward & $25 \mathrm{nt}$ & TTTCСТСТGTССТСАTTCACAAACG & \\
\hline LAMP & F3 & Forward outer & $18 \mathrm{nt}$ & AAGTAAGTGGGATCTACG & \multirow{6}{*}{$\begin{array}{l}\text { Fragment with } \\
\text { different sizes }\end{array}$} \\
\hline LAMP & B3 & Backward outer & $21 \mathrm{nt}$ & GAAATGCAAGAATGGGCTGAT & \\
\hline LAMP & FIB & Forward inner & $47 \mathrm{nt}$ & GGCCCACAATTACATCACAGGGCTTTTGACGTTGTATTCCACTTCAT & \\
\hline LAMP & BIP & Backward inner & $53 \mathrm{nt}$ & CCACATAGTCTTCCCTGTTCTTGATTTTTATTTTGGGGTTGATGCCGCTGCGC & \\
\hline LAMP & LF & Loop forward & $23 \mathrm{nt}$ & TAGATTTTAGCCTTAGAACATAT & \\
\hline LAMP & LB & Loop backward & $21 \mathrm{nt}$ & ACTATGATACTATTATATCTT & \\
\hline
\end{tabular}

Table 1: Oligonucleotide primers used for PCR and LAMP to detection of CTV. 
Citation: Almasi MA, Aghapour-Ojaghkandi M, Aghaei S (2013) Visual Detection of Curly Top Virus by the Colorimetric Loop-Mediated Isothermal Amplification. J Plant Pathol Microb 4: 198 doi:10.4172/2157-7471.1000198

Page 3 of 6

2041 ccacctttaa tgacacgtgg ttttccatac tttaagtttg tctgecactc cttttgtgct

F

F3

$2101 \underset{\text { ccaataaggt gcttccagtg tttcatcttt aagtaagtgg gatctacgtc atcaatgacg }}{\stackrel{\text { F2 }}{\longrightarrow}}$
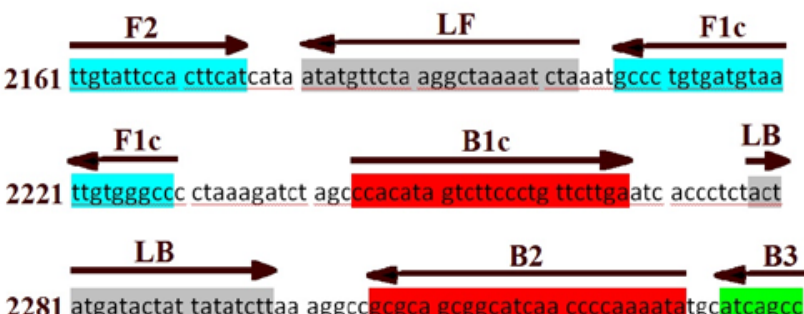

B3

B

2341 cattcttgca tttcctcagg aacgtttgtg aatgaggaca gaggaaatag tggagtccat

Figure 1: Schematic representation of position and sequence of CTV-specific primer pair used in PCR and LAMP analysis on rep gene. F1c plus F2 formed FIP and B1c plus B2 formed BIP.
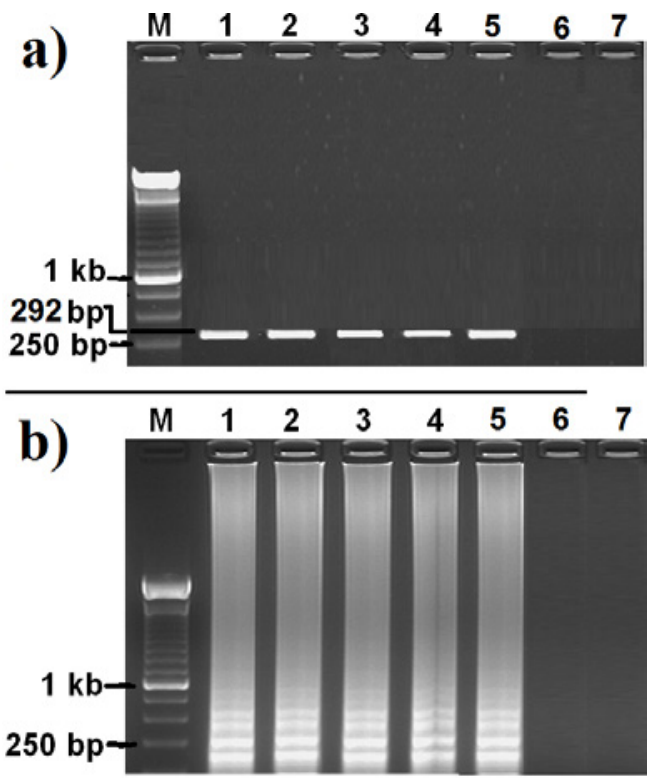

Figure 2: Analysis of products for the detection of CTV (a) PCR products on agarose gel; (b) LAMP products on agarose gel. Left to right: lane M, DNA size marker (1 kb; Fermentas); Lane 1, CTV24; lane 2, CTV36; lane 3, CTV42; lane 4, CTV45; lane 5positive control (BCTV); lane 6, water control; lane 7, negative sample.

pyrophosphate-based detection method, an alternative visual system using SYBR ${ }^{\circledR}$ Premix Ex Taq ${ }^{\mathrm{TM}}$ II was employed [34,42]. Hence, $2 \mu \mathrm{l}$ SYBR $^{\circledR}$ Premix Ex Taq ${ }^{\mathrm{TM}}$ II (Perfect Real Time, Takara Bio Co., Ltd., RR081A) was added into each completely finished LAMP reaction containing $25 \mu \mathrm{l}$ LAMP products.

\section{Hydroxynaphthol blue (HNB)}

In this protocol, $1 \mu \mathrm{l}$ of the hydroxylnaphthol blue dye $(3 \mathrm{mM}$, Lemongreen, Shanghai, China) is mixed prior to amplification; all positive reactions can be easily identified using the naked eye, interestingly with no probable cross contaminations which usually arise from opened tubes after amplification [31-33,38,41].

\section{GeneFinder $^{\mathrm{TM}}$}

An obvious Green fluorescence pattern was observed to confirm positive LAMP products through visual observation with the naked eye when $1 \mu \mathrm{l}$ of GeneFinder ${ }^{\mathrm{TM}}$, diluted to $1: 10$ with $6 \times$ loading buffer (Biov. Bio. Xiamen, China), was added to each reaction as described previously $[30,36,39,41]$.

\section{SYBR Green I}

About $1 \mu$ of SYBR Green I (Invitrogen, Sydney, Australia) diluted to $1: 10$ with $6 \times$ loading buffer was separately added to each reaction as described previously [33,38]. After addition of SYBR Green I, the products can be visualized directly by the naked eye.

\section{Ethidium bromide}

Under a UV transilluminator, positive products will be consequently marked if a detectable yellow colour pattern is observed [24]. Ethidium bromide is a polycyclic fluorescent dye that binds to double-stranded DNA molecules by intercalating a planar group between the stacked base pairs of the nucleic acid [34-37]. About $0.5 \mu \mathrm{g}$ ethidium bromide/ $\mathrm{ml}$ (Sigma) was added to each tube as designed previously by Tsai et al. [35].

\section{Results}

On the whole, 4 out of 83 leaf samples suspicious of having infection with CTV (CTV24, CTV36, CTV42 and CTV45) (4.8\%) showed positive responses. When PCR was used for the detection of CTV, band of approximately $292 \mathrm{bp}$ was amplified and visualized under UV light (Figure 2a). The LAMP technique can from amplified products of various sizes, consisting of alternately inverted repeats of the target (a)

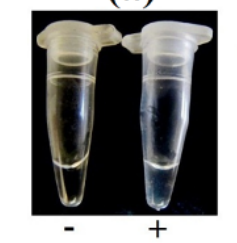

(d) (b)

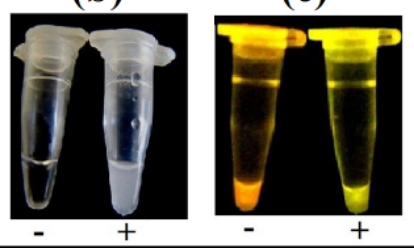

(e) (f)

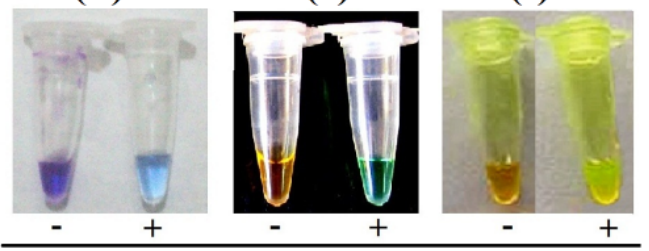

(g)

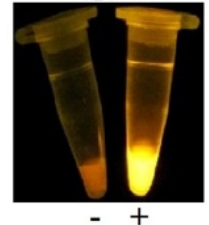

Tube +: Positive sample

Tube -: negative sample

Figure 3: Visual detection of LAMP with different dyes (a) visual detection by magnesium pyrophosphatebased method; (b) visual detection by calcium pyrophosphate-based method; (c) visual detection by SYBR® Premix Ex TaqTM II-based method; (d) visual detection by hydroxynaphthol blue (HNB)based method; (e) visual detection by GeneFinderTM based method; (f) visual detection by SYBR Green I-based method; (g) visual detection by ethidium bromide-based method. 
sequence on the same strand. Therefore, the LAMP primers generated many fragments with different sizes and formed a ladder pattern on an agarose gel (Figure 2b). LAMP amplicons were able to be detected with the naked eye by adding different visual dyes followed by color changing in the solutions. In this regard, all used visual components could successfully make a clear distinction between positive infected samples and negative ones. In the LAMP reaction when DNA polymerizes, producing pyrophosphate ions and interaction between pyrophosphate and magnesium or calcium lead to produce magnesium pyrophosphate or calcium pyrophosphate (white precipitate) which can be observed and detectable as turbidity in positive samples. In contrast, negative control remains transparent without any turbidity (Figure 3a and $3 \mathrm{~b}$ ). The $\mathrm{CaCl}_{2}$ was improved both stability and concentration of turbidity in contrast of $\mathrm{MgSO}_{4}$. Under UV illumination (302 nm), a green color pattern is an identical characteristic of all positive reactions was monitored in this study after was used SYBR ${ }^{\circledR}$ Premix Ex Taq ${ }^{\mathrm{TM}}$ II (Figure 3c). When HNB was used for detect, a sky blue color pattern implies the existence of the reference virus, whereas a violet color change is observed when the control(s) are taken into consideration (Figure 3d). An obvious green fluorescence pattern was observed to confirm positive LAMP products through visual observation with the naked eye when GeneFinder ${ }^{\mathrm{TM}}$ or SYBR Green I were added to each reaction. Remarkably, concerning negative reaction, the original orange color could be observed (Figures $3 e$ and $3 f$ ). Under a UV transilluminator, also a detectable yellow color pattern is observed when ethidium bromide was applied to detection of positive reaction (Figure $3 \mathrm{~g}$ ). As a result, the intensity of the fluorescent emissions moves up in positive tubes, while the reverse is true regarding negative tubes with no amplified fragments. More interestingly, in some cases, just a little fluorescent emission could be observed in negative tubes, presumably arising from the presence of primers and/or DNA templates, leading to an increase to false positive outputs.

\section{Discussion}

Curly top virus (CTV) and related viruses (collectively known as curtoviruses) have caused significant problems to irrigated agriculture in Iran. CTV is known to infect a broad range of crop and weed hosts in many plant families. Crop hosts for which natural CTV infection has been reported include sugar beet, tomato, pepper, bean, spinach, and cucurbits [7,22]. Molecular methods including polymerase chain reaction (PCR), Rolling-circle amplification (RCA), Restriction fragment length polymorphism (RFLP) and Chromatin immunoprecipitation (ChIP) assays, are specific and accurate approaches, but most are technically demanding and time-consuming techniques, needing post-process stage or costly detection equipment to visualize amplified DNA [20-22]. Thus, an inexpensive and rapid diagnostic method is required, especially in developing countries with insufficient facilities. The LAMP assay was first applied for detection of yam mosaic virus [27]. In this study, for the first time, a colorimetric LAMP method with the use of different dyes was developed and optimized. In reality, LAMP overall requires just $30 \mathrm{~min}$ to accomplish while PCR method $3 \mathrm{~h}$ should be served (Table 2). This, in turn, would simplify the detection procedure and result in saving of significant time needing for separating of the amplified products on the gel and the analyzing of the data. Safety regarding a number of detection methods, application of gel electrophoresis systems has emerged as a routine approach with enough potential to observe related amplicons. Just the same, such visual methods not only involve some expensive instruments but also during a period of time, exposure to the UV ray (because it is harmful to the eyes, even watching for a short period would irritate eyes and cause symptoms similar to conjunctivitis) as well as ethidium bromide could accompany a number of serious negative effects on researchers who use these methods [34-43]. More surprisingly, in LAMP, amplified products can be easily visualized by means of different in tube color indicators with no essential requirement of additional staining systems; thus, toxic staining materials would be significantly avoided. Simplicity, cost and user-friendly equipped labs with some molecular instruments as well as trained personnel are prerequisites to perform other assays, all of which are undoubtedly costly. On the contrary, LAMP can be easily accomplished just in a water bath or temperature block with no need of thermocyler and gel electrophoresis $[27,44]$.

According to our results, despite the precise detection of positive LAMP products using all dyes, some were significantly superior when the time of stability, cost and the safety were taken into consideration (Table 3). For instance, regardless of its reasonable color change stability ( $\geq 2$ weeks), when employing ethidium bromide, a UV transilluminator must be available, both of which are toxic, resulting in deleterious consequences on human health and the environment [34,43]. As the

\begin{tabular}{|c|c|c|c|c|c|c|c|c|}
\hline Assay & Total time & Detection method & Safety & $\begin{array}{l}\text { Need to UV } \\
\text { ray }\end{array}$ & $\begin{array}{l}\text { Need to detect } \\
\text { instruments }\end{array}$ & Cost & User Friendly & Accuracy \\
\hline PCR & 3 hours & $\begin{array}{l}\text { Gel } \\
\text { Electrophoresis }\end{array}$ & No & Yes & Yes & High & Low & High \\
\hline LAMP & 30 minutes & $\begin{array}{l}\text { Visual+ Gel } \\
\text { Electrophoresis }\end{array}$ & Yes & No and Yes & No and Yes & Low & High & High \\
\hline Colorimetric LAMP & 30 minutes & Visual & Yes & No & No & Low & Very high & High \\
\hline
\end{tabular}

Table 2: Comparison of PCR, LAMP and colorimetric LAMP assays for detection of CTV.

\begin{tabular}{|c|c|c|c|c|c|c|c|c|}
\hline Visual system & $\begin{array}{l}\text { Detection } \\
\text { method }\end{array}$ & Safety & $\begin{array}{l}\text { Positive } r \\
\text { eaction }\end{array}$ & Negative sample & $\begin{array}{l}\text { Need to } \\
\text { UV ray }\end{array}$ & Stability & $\begin{array}{l}\text { Cross } \\
\text { contamination }\end{array}$ & Use time \\
\hline magnesium Sulfate & Visual & Yes & Turbidity & No turbidity & No & $5-10$ seconds & No & Before the amplification \\
\hline Calcium chloride & Visual & Yes & Turbidity & No turbidity & No & $40-60$ seconds & No & Before the amplification \\
\hline $\begin{array}{l}\text { SYBR }^{\circledR} \text { Premix Ex } \\
\text { Taq }^{\text {TM }} \text { II }\end{array}$ & Visual & Yes & Green & Red & Yes & $1-3$ days & Yes & After the amplification \\
\hline Hydroxynaphthol blue & Visua & Yes & Sky blue & Violet & No & 2-3 weeks & No & Before the amplification \\
\hline GeneFinder $^{\mathrm{TM}}$ & Visual & Yes & Green & Red & No & 2-3 weeks & No & Before the amplification \\
\hline SYBR Green I & Visual & Yes & Green & Red & Yes & 2-3 weeks & No & Before the amplification \\
\hline Ethidium bromide & Visual & No & Yellow & No color & Yes & 2 weeks & Yes & After the amplification \\
\hline
\end{tabular}

Table 3: Comparison of colorimetric assays together. 
last drawback, the corresponding lab(s) should be equipped with such instruments which are commonly costly. Alternatively, to remedy such problems, the first metal dye called $\mathrm{MgSO}_{4}$ and $\mathrm{CaCl}_{2}$ was utilized, but just an ephemeral color change (i.e. turbidity; no more than a few seconds or minutes) was observed in tubes [24,35]. Even though short stability of the colour change probably cannot be a significant problem as long as just a few numbers of suspicious samples are used, during assessment of a great quantity of infected samples, most of the time, inaccurate results will be accordingly achieved [36-41]. The method, nevertheless, since in one hand is exploited prior to the reaction, leading to a significant reduction on probable contaminations, and on the other there is no need of toxic devices, could be thereby attributed as a reliable visual observation approach. Anyway, to provide a situation to increase time stability, the second fluorescent dye coined $S_{Y B R}{ }^{\circledR}$ Premix Ex $\mathrm{Taq}^{\mathrm{TM}}$ II was employed, leading to a clear green colour pattern. Notably, regardless of observing a significant growth on time stability (about 1-3 days), the method not only requires UV transilluminator but also its stability is more negatively sensitive when amplified reactions are exposed to the daylight. Indeed, since the dye must be added after the amplification so requires opening of the tubes, the occurrence of cross contamination risk will be accordingly enhanced [42]. To avoid such contaminations, using separate rooms can be a solution for LAMP setup and analysis [31]. Interestingly, HNB, SYBR Green I and GeneFinder ${ }^{\mathrm{TM}}$ dye-based assays were accompanied by several remarkable advantages compared with other colorimetric-based methods in that of which are mixed prior to amplification, a need to open the assayed samples to add the dye is thereby omitted, and the risk of cross-contamination will be excluded drastically [31-33,42]. Meanwhile, the visual inspection of LAMP products by means of the dyes was seen as advantageous as there was no need for electrophoresis and subsequent staining with carcinogenic ethidium bromide [30]. Lastly, the color brightness and stability of the both HNB, SYBR Green I and GeneFinder ${ }^{\mathrm{TM}}$ in the solutions with positive/negative reactions were remained constant after 2 weeks of exposure to ambient light, whereas detection by SYBR ${ }^{\circledR}$ Premix Ex Taq ${ }^{\mathrm{TM}}$ II was stable only 1-3 days. For example, at the study of Goto et al. [31], HNB was reported as the best visual system, while the brightness of SYBR green fluorescence and calcein fluorescence was significantly weaker than that of HNB. It is noticeable that since the color presented by HNB was light blue for positive results and dark blue for negative results, which cannot be discriminated precisely [42], so such based detection methods involve a little more attention to provide accurate decision. From the present study it is concluded that colorimetric LAMP could be a reliable and rapid technique that can help at the maximum to this direction.

\section{Acknowledgement}

This research was supported financially by Young Researchers and Elite Club, Meybod Branch, Islamic Azad University and desert trier biotechnologist Co. of Meybod.

\section{References}

1. Creamer R, Luque Williams M, Howo M (1996) Epidemiology and incidence of beet curly top geminivirus in naturally infected weed hosts. Plant Dis 80 : 533-535.

2. Briddon RW, Stenger DC, Bedford ID, Stanley J, Izadpanah K, et al. (1988) Comparison of a beet curly top virus isolate originating from the old world with those from the new world. Eur J Plant Pathol 104: 77-84.

3. Stenger DC (1998) Replication Specificity Elements of the Worland Strain of Beet Curly Top Virus Are Compatible with Those of the CFH Strain But Not Those of the Cal/Logan Strain. Phytopathology 88: 1174-1178.

4. Ke G (1967) Possible incidence of curly top in Iran a new record. Plant Dis 51: 976-977
5. Bennett CW (1971) The curly top disease of sugarbeet and other plants. Am Phytopathol Soc 7: 81 .

6. Briddon RW, Heydarnejad J, Khosrowfar F, Massumi H, Martin DP, et al. (2010) Turnip curly top virus, a highly divergent geminivirus infecting turnip in Iran. Virus Res 152: 169-175.

7. Heydarnejad J, Hosseini Abhari H, BolokYazdi HR, Massumi H (2007) Curly top of cultivated plants and weeds and report of a unique curtovirus from Iran. J Phytopathol 155: 321-325.

8. Yazdi HR, Heydarnejad J, Massumi H (2008) Genome characterization and genetic diversity of beet curly top Iran virus: a geminivirus with a novel nonanucleotide. Virus Genes 36: 539-545.

9. Hormuzdi SG, Bisaro DM (1993) Genetic analysis of beet curly top virus: evidence for three virion sense genes involved in movement and regulation of single- and double-stranded DNA levels. Virology 193: 900-909.

10. Kaffka SR, Wintermantel WM, Lewellen RT (2002) Comparisons of soil and seed applied systemic insecticides to control beet curly top virus in the San Joaquin Valley. J Sugar Beet Res 39: 59-74.

11. Klute KA, Nadler SA, Stenger DC (1996) Horseradish curly top virus is a distinct subgroup II geminivirus species with rep and C4 genes derived from a subgroup III ancestor. J Gen Virol $77: 1369-1378$.

12. Stenger DC, Ostrow KM (1996) Genetic complexity of a beet curly top virus population used to assess sugar beet cultivar response to infection. Phytopatho 86: 929-933.

13. Creamer R, Hubble $\mathrm{H}$, Lewis A (2005) Curtovirus infection in chile pepper in New Mexico. Plant Dis 89: 480-486.

14. Stanley J, Markham PG, Callis RJ, Pinner MS (1986) The nucleotide sequence of an infectious clone of the geminivirus beet curly top virus. EMBO J 5: 1761 1767

15. Choi IR, Stenger DC (1996) The strain-specific cis-acting element of beet curly top geminivirus DNA replication maps to the directly repeated motif of the ori. Virology 226: 122-126.

16. Soto MJ, Chen LF, Seo YS, Gilbertson RL (2005) Identification of regions of the Beet mild curly top virus (family Geminiviridae) capsid protein involved in systemic infection, virion formation and leafhopper transmission. Virology 341 : 257-270.

17. Stanley J, Latham JR, Pinner MS, Bedford I, Markham PG (1992) Mutational analysis of the monopartite geminivirus beet curly top virus. Virology 191: 396405 .

18. Stenger DC, Davis KR, Bisaro DM (1994) Recombinant beet curly top virus genomes exhibit both parental and novel pathogenic phenotypes. Virology 200 677-685.

19. Duffus JE, Skoyen IO (1977) Relationship of age of plants and resistance to a severe isolate of the beet curly top virus. Phytopathol 67: 151-154.

20. Heydarnejad J, Keyvani N, Razavinejad S, Massumi H, Varsani A (2013) Fulfilling Koch's postulates for beet curly top Iran virus and proposal for consideration of new genus in the family Geminiviridae. Arch Virol 158: 435443.

21. Demidov V (2005) Rolling-circle amplification (RCA). Encycl Diag Genom Proteom 10: 1175-1179.

22. Johnson L, Cao X, Jacobsen $S$ (2002) Interplay between two epigenetic marks. DNA methylation and histone H3 lysine 9 methylation. Curr Biol 12: 1360-1367.

23. Strausbaugh CA, Wintermantel WM, Gillen AM, Eujayl IA (2008) Curly top survey in the Western United States. Phytopathology 98: 1212-1217.

24. Notomi T, Okayama H, Masubuchi H, Yonekawa T, Watanabe K, et al. (2000) Loop-mediated isothermal amplification of DNA. Nucleic Acids Res 28: E63.

25. Mori Y, Notomi T (2009) Loop-mediated isothermal amplification (LAMP): a rapid, accurate, and cost-effective diagnostic method for infectious diseases. J Infect Chemother 15: 62-69.

26. Nagamine K, Kuzuhara Y, Notomi T (2002) Isolation of single-stranded DNA from loop-mediated isothermal amplification products. Biochem Biophys Res Commun 290: 1195-1198.

27. Fukuta S, lida T, Mizukami Y, Ishida A, Ueda J, et al. (2003) Detection of Japanese yam mosaic virus by RT-LAMP. Arch Virol 148: 1713-1720. 
Citation: Almasi MA, Aghapour-Ojaghkandi M, Aghaei S (2013) Visual Detection of Curly Top Virus by the Colorimetric Loop-Mediated Isothermal Amplification. J Plant Pathol Microb 4: 198 doi:10.4172/2157-7471.1000198

28. Varga A, James $D$ (2006) Use of reverse transcription loop-mediated isothermal amplification for the detection of Plum pox virus. J Virol Methods 138: 184-190.

29. Nie $X$ (2005) Reverse transcription loop-mediated isothermal amplification of DNA for detection of potato virus Y. Plant Dis 89: 605-610.

30. Ren WC, Wang CM, Cai YY (2009) Loop-mediated isothermal amplification for rapid detection of acute viral necrobiotic virus in scallop Chlamys farreri. Acta Virol 53: 161-167.

31. Goto M, Honda E, Ogura A, Nomoto A, Hanaki K (2009) Colorimetric detection of loop-mediated isothermal amplification reaction by using hydroxy naphtho blue. Biotechniques 46: 167-172.

32. Cardoso TC, Ferrari HF, Bregano LC, Silva-Frade C, Rosa AC, et al. (2010) Visual detection of turkey coronavirus RNA in tissues and feces by reversetranscription loop-mediated isothermal amplification (RT-LAMP) with hydroxynaphthol blue dye. Mol Cell Probes 24: 415-417.

33. Ma XJ, Shu YL, Nie K, Qin M, Wang DY, et al. (2010) Visual detection of pandemic influenza A H1N1 Virus 2009 by reverse-transcription loop-mediated isothermal amplification with hydroxynaphthol blue dye. J Virol Methods 167: 214-217.

34. Moradi A, Nasiri J, Abdollahi H, Almasi M (2012) Development and evaluation of a loop-mediated isothermal amplification assay for detection of Erwinia amylovora based on chromosomal DNA. Eur J Plant Pathol 133: 609-620.

35. Tsai SM, Chan KW, Hsu WL, Chang TJ, Wong ML, et al. (2009) Development of a loop-mediated isothermal amplification for rapid detection of orf virus. J Virol Methods 157: 200-204

36. Almasi MA, Erfan Manesh M, Jafary H, Dehabadi SM (2013) Visual detection of Potato Leafroll virus by loop-mediated isothermal amplification of DNA with the GeneFinder $^{\mathrm{TM}}$ dye. J Virol Methods 192: 51-54
37. Almasi MA, Hosseini SMD, Moradi A, Eftekhari Z, Ojaghkandi MA et al. (2013) Development and application of loop-mediatred Isothermal amplification assay for rapid detection of fusariumoxysporum $f$. sp. Lycopersici. J Plant Patho Microbiol.

38. Almasi MA, Jafary H, Moradi A, Zand N, Ojaghkandi MA, et al. (2013) Detection of Coat Protein Gene of the Potato Leafroll Virus by Reverse Transcription Loop-Mediated Isothermal Amplification. J Plant Pathol Microbiol.

39. Almasi MA, Moradi A, Nasiri J, Karami S, Nasiri M (2012) Assessment of performance ability of three diagnostic methods for detection of Potato Leafroll virus (PLRV) using different visualizing systems. Appl Biochem Biotechnol 168: 770-784.

40. Almasi MA, Ojaghkandi MA, Hemmatabadi A, Hamidi F, Aghaei S (2013) Development of Colorimetric Loop-Mediated Isothermal Amplification Assay for Rapid Detection of the Tomato Yellow Leaf Curl Virus. J Plant Pathol Microbiol.

41. Ahmadi S, Almasi MA, Fatehi F, Struik PC, Moradi A (2012) Visual Detection of Potato leafroll virus by One-step Reverse Transcription Loop-Mediated Isothermal Amplification of DNA with Hydroxynaphthol Blue Dye. J phytopathol 161: 120-124.

42. Cheng SJ, Chen ZY, Chu YN, Cui LB, Shi ZY, et al. (2011) Sensitive detection of influenza $\mathrm{A}(\mathrm{H} 1 \mathrm{~N} 1)$ virus by isothermal amplification in a single tube. Chin $\mathrm{J}$ Anal Chem 39: 335-340.

43. Tomita N, Mori Y, Kanda H, Notomi T (2008) Loop-mediated isotherma amplification (LAMP) of gene sequences and simple visual detection of products. Nat Protoc 3: 877-882.

44. Soliman H, El-Matbouli M (2009) Immunocapture and direct binding loop mediated isothermal amplification simplify molecular diagnosis of Cyprinid herpesvirus-3. J Virol Methods 162: 91-95. 